DOI: https://doi.org/10.37634/efp.2021.7.4

УДК 658:351.78

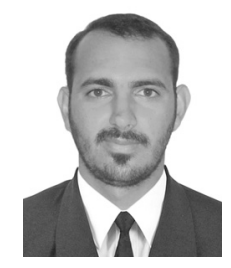

Taleb Abdullah Mohammed Ali ALHAMMADI

postgraduate student, State University "Odesa Polytechnic".

ORCID: https://orcid.org/0000-0001-8364-989X

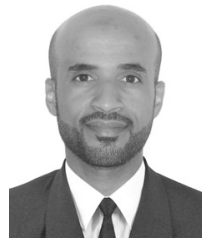

Hamed Rashed Sayed Abdullah ALNUAIMI

postgraduate student, State University "Odesa Polytechnic".

ORCID: https://orcid.org/0000-0002-2479-1244

\title{
EMERGENCIES IN UKRAINE: ANALYTICAL AND STATISTICAL STUDY
}

Introduction. Knowledge of the causes and nature of emergencies allows for the early adoption of protective measures with reasonable behaviour to reduce all types of damage significantly. Preliminary information for business structures makes it possible to carry out preventive work, alert forces and means, explain to people the rules of conduct. All business structures and the population must be ready to act in extreme situations, participate in the elimination of natural disasters, accidents and catastrophes, to master the methods of providing first aid to victims. To address these issues, most developed countries in Europe and America have established unique medical systems, the main tasks of responding to emergencies and participating in eliminating health consequences.

The purpose of the paper is to study the level of emergencies in Ukraine and develop preventive measures for business structures.

Results. In 2020, 116 emergencies were registered in Ukraine, including 40.2\% of man-made nature; natural nature - 54.7\%; social nature - 5.1\%. The human disease was also significantly affected by the COVID-19 coronavirus - 18,680 deaths in 2020. Compared to 2019, the total number of emergencies in 2020 decreased by $20.5 \%$. The analysis showed that the most common sources of man-made emergencies are fires and explosions that occur at industrial facilities, so the authors proposed precautionary measures for business structures, which include measures to address the causes that could lead to the occurrence of fire (explosion), to limit (localize) the spread, to create conditions for the evacuation of people and property, timely detection of fire and notification of it, extinguishing the fire, maintaining the fire fighting forces in constant readiness.

Conclusion. The study showed that the number of emergencies is small and can be observed in some species in 2020, but each emergency is a human life, so it is necessary to strive for their number to lead to 0 . The proposed measures will allow businesses to anticipate emergencies more effectively.

Keywords: emergencies, business structures, statistics

\section{INTRODUCTION}

Knowledge of the causes and nature of emergencies allows, with early adoption of protective measures, with reasonable behaviour, to significantly reduce all types of losses $[1 ; 2]$. Advance information for business structures makes it possible to carry out preventive work, alert forces and means, explain to people the rules of behaviour. All business structures and the population should be ready to act in extreme situations, participate in the elimination of natural disasters, accidents and catastrophes, to master the methods of providing first aid to victims [3]. To address these issues, most developed countries in Europe and America have created unique medical systems, the main tasks of responding to emergencies and participating in eliminating their health consequences.

The PURPOSE of the paper is to study the level of emergencies in Ukraine and develop Preventive measures for business structures.

\section{RESEARCH METHODS}

The methodological and informational basis of the work is scientific works, materials of periodicals, Internet resources.

In 2020, 116 emergencies were registered in Ukraine, which according to the National Classifier "Classifier of Emergencies" DK 019: 2010 were divided into: technogenic nature - 47; natural - 64; social nature - 5 [4].

As a result of emergencies, in 2020, 170 people died (including 26 children), and 305 people were injured (including 46 children). According to the Ministry of Health of Ukraine, as of January 1, 2021, 1064479 cases of human coronavirus COVID-19 were registered in Ukraine, of which 18680 cases were fatal.

The scale of emergencies that arose in 2020 was divided into:

- state level - 6;

- regional level -4;

- local level - 50;

- object level - 56 .

Compared to 2018, the total number of emergencies in 2019 increased by $14.1 \%$, while the number of manmade emergencies increased by $25 \%$ (due to an increase in the number of emergencies due to fires and explosions, 
accidents on life support systems and sudden destruction of buildings), the number of natural disasters - by $5.2 \%$ (due to a 4-fold increase in the number of meteorological emergencies). In the reporting period, there was an increase of $78 \%$ in the number of victims (mainly due to medical and biological emergencies) and $18.5 \%$ in the number of deaths in emergencies (mainly due to emergencies due to traffic accidents and fires, explosions in buildings and structures) (Fig. 1).

Compared to 2019, the total number of emergencies in 2020 decreased by $20.5 \%$, while the number of manmade emergencies decreased by $21.7 \%$ (primarily due to a decrease of $60 \%$ in the number of emergencies in life support systems, $19 \%$ - emergencies in transport, by $8 \%$ - emergencies due to fires and explosions), and the Number of emergencies number of natural disasters - by $21 \%$ (a decrease of $42 \%$ in the number of medical and biological emergencies, primarily caused by food poisoning, but an increase of more than 1.6 times the number of emergencies due to fires in natural ecosystems).

In 2020, the lowest number of emergencies was recorded during the observation period since 1997, while the scale of emergencies increased and the amount of damage caused by emergencies increased more than 6 times, primarily due to emergencies related to forest fires in April (Zhytomyr region and Exclusion Zone), July (Luhansk region) and September (Kharkiv and Luhansk regions), droughts caused by droughts in Odesa and Vinnytsia regions, as well as emergencies due to the June floods in the western oblasts of Ukraine (Fig. 2).

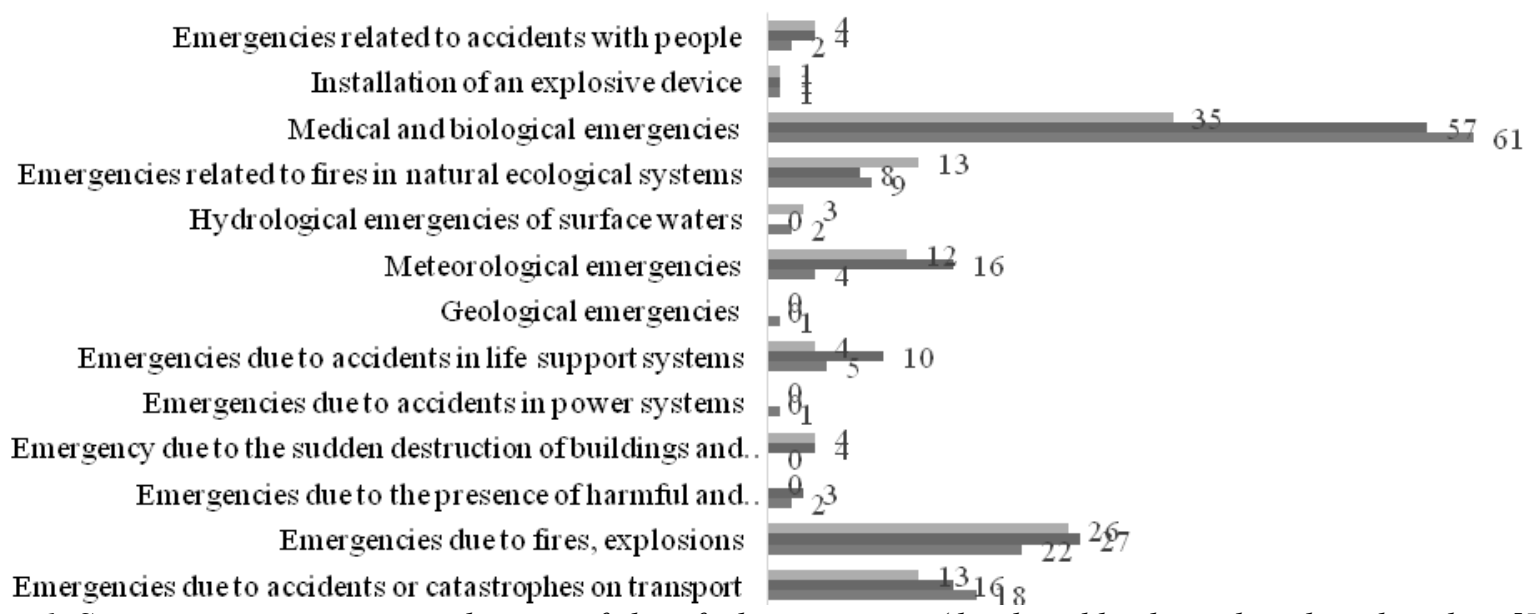

Fig. 1. Statistics on quantitative indicators of classified emergencies (developed by the authors based on data [5])

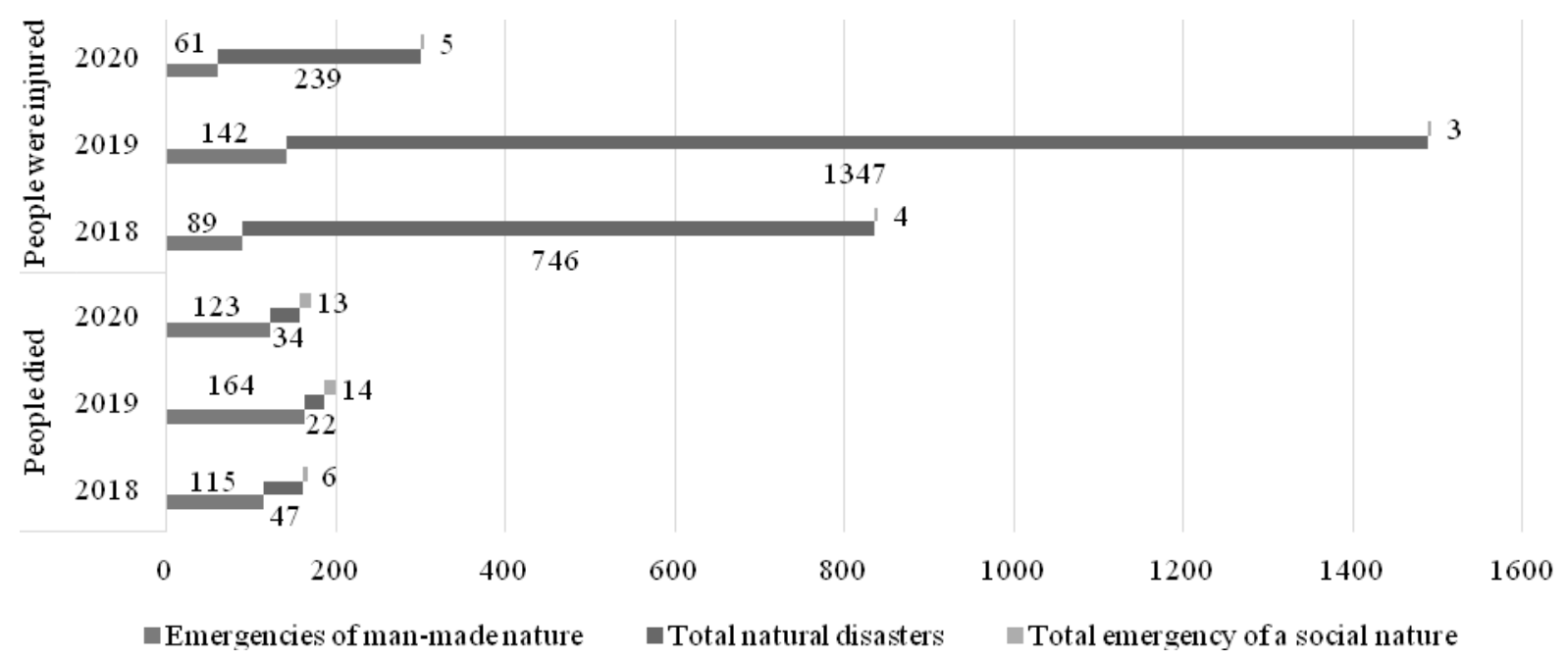

Fig. 2. Statistics on the affected population (developed by the authors based on data [5])

State-level emergencies occurred as a result of:

- spread of acute respiratory disease COVID-19 caused by coronavirus SARS-CoV-2 on the territory of Ukraine $[3 ; 6]$. According to the Ministry of Health, as of January 1, 2021, 1064,479 cases of human coronavirus COVID19 were registered in Ukraine, of which 18,680 cases were fatal;

- mass drying and death of crops due to drought in the Odesa region, according to the Odesa regional state administration (letter from 30.06.2020 № 1/01-39/4696/
2-20), 1311 farms of the region suffered losses amounting to 6649.88 million UAH due to the death of crops on the area of 498662.54 hectares;

- complication of weather conditions, heavy rainfall in the Transcarpathian, Ivano-Frankivsk, Lviv, Ternopil and Chernivtsi regions in the period from June 12 to June 24, 2020, which led to sharp rises in water levels in river basins, complicating the flood situation and flooding 349 settlements, more than 14.3 thousand houses, flooded more than 22.4 thousand homesteads, damaged 3.5 thousand 
farm buildings, destroyed and damaged more than 940 $\mathrm{km}$ of roads, more than $140 \mathrm{~km}$ of fortifications, more than $20 \mathrm{~km}$ of dams and more than 300 bridges. As a result of the emergency, five people died (including one child). The amount of direct material damage caused by the emergency, according to regional state administrations, is more than 1.3 billion UAH;

- forest fire that occurred on July 6, 2020, in the territory of Borivskyi and Okhtyrskyi forestries in Novoaidarskyi district of Luhansk region, which due to strong gusts of wind (up to $25 \mathrm{~m} / \mathrm{s}$ ) variable directions and high air temperature $\left(+38{ }^{0} \mathrm{C}\right)$ spread to coniferous forest quarters nearby the villages of Kapitanove and Voronove, as well as the territory of the village of Smolianinove. The total area of the fire is about 5 thousand hectares; as a result of the fire, 35 houses were destroyed, and 24 houses in the village were damaged. Smolianinove and destroyed 49 country houses of the horticultural society №5 "Wolf Lake" Novoaidar district.

More than 1.4 thousand people and 250 units of equipment were involved in extinguishing the fire, including 736 people and 147 units from the SES. Equipment (including $2 \mathrm{AN}-32 \mathrm{P}$ aircraft). According to the Luhansk Regional State Administration, the region's forestry suffered losses amounting to more than 284 million UAH;

- crash of the AN-26 aircraft of the Armed Forces of Ukraine near the military airfield in Chuhuiev (Kharkiv region). As a result of the emergency, 26 people died, and 1 person was injured;

- fires in natural ecosystems (146 fires), which occurred during September 30 - October 1 on the territory of Stanychno-Luhansk, Severodonetsk and Novoaidar forestry of Luhansk region. Due to challenging weather conditions (wind with hurricane gusts up to $25 \mathrm{~m} / \mathrm{s}$, long dry period), the fires quickly spread over a large area of over 20 thousand hectares and became threatening to human settlements. The most challenging situation developed along the demarcation line in Stanychno-Luhansk, Novoaidar, Severodonetsk districts, where 32 settlements fell into the affected area. The fire confirmed the death of 10 people, injured (caused damage to health) 17 people, the fire destroyed and damaged about 250 buildings, evacuated 150 people. More than 2,500 people were involved in extinguishing the fire and more than 250 units of equipment, from the SES 687 people and 158 units of equipment, including $3 \mathrm{AN}-32 \mathrm{P}$ fire planes and two helicopters. According to the Luhansk Regional State Administration (ref. № 1-09/00202 dated 05.10.20), the emergency losses are more than 25 thousand minimum wages. The calculation of the amount of damage caused by the emergency continues.

Three emergencies at the regional level occurred as a result of fires in natural ecosystems, namely:

- forest fire that broke out on April 3, 2020, near the village of Zvizdal of Narodytskyi district on the territory of Narodytskyi and Klishchivskyi forestries of SE "Narodytskyi spetslishosp" of Zhytomyr region with the further spread of fire to the territory of Narodytskyi, Davydkivskyi, Klishchyvskyi forestry of Narodytskyi district of Zhytomyr region and Denysovetsky, Dytiatkivskyi, Paryshkivskyi and Korohodyskyi unconditional (compulsory) resettlement. More than 1,300 people and 300 units of equipment, including three planes and three SES helicopters, were involved in extinguishing the fire every day. In the cluttered forests of the Exclusion Zone with heavy engineering equipment of the SES.

The most common sources of man-made emergencies are fires and explosions that occur $[6 ; 7]$ :

- at industrial facilities;

- at facilities for the production, storage and processing of flammable, combustible and explosive substances;

- on transport;

- in mines, mine workings, subways;

- in buildings and structures of residential, social and cultural purposes.

A fire is a burning process out of control that destroys material values and poses a threat to the life and health of people.

The main causes of fire in business structures are: malfunctions in electrical networks, violation of the technological regime and fire safety measures (smoking, making an open fire, using faulty equipment, etc.).

The main hazards of fire are thermal radiation, high temperatures, the toxic effect of smoke (combustion products: carbon monoxide, etc.) and reduced visibility during the smoke. The critical values of the parameters for a person, with prolonged exposure to the specified values of hazardous fire factors, are: temperature $-70{ }^{\circ} \mathrm{C}$; thermal radiation density $-1.26 \mathrm{~kW} / \mathrm{m}^{2}$; the concentration of carbon monoxide $-0.1 \%$ by volume; visibility in the smoke zone - 6-12 $\mathrm{m}$.

An explosion is a combustion accompanied by the release of a large amount of energy in a limited volume in a short period. The explosion leads to the formation and propagation of a blast shock wave at a supersonic speed (with an excess pressure of more than $5 \mathrm{kPa}$ ), which exerts a mechanical shock effect on the surrounding objects.

The main damaging factors of the explosion are an air shock wave and fragmentation fields formed by flying debris of various kinds of objects, technological equipment, and explosive devices.

Preventive measures for business structures:

The number of preventive measures may include measures aimed at eliminating the causes that can cause a fire (explosion), at limiting (localizing) the spread of fires, creating conditions for the evacuation of people and property in case of fire, timely fire detection and notification, fire extinguishing keeping fire suppression forces in constant readiness.

Compliance with technological modes of production, the maintenance of equipment, especially energy networks, in good condition allows, in most cases, to exclude the cause of the fire.

Timely fire detection can be achieved by equipping industrial and domestic premises with automatic fire alarm systems or, in some cases, by using organizational measures.

Initial fire extinguishing (before the arrival of the forces caused) is successfully carried out at facilities equipped with automatic fire extinguishing installations.

\section{CONCLUSIONS}

Not every initial natural or man-made phenomenon can be considered an emergency. A system of criteria determines the fact of an emergency. The basis of the system of standards that determine the presence of emergencies and characterize them in terms of the scale and degree of damage is the principle of fixation. The number of affected 
residents, the presence of material damage, the scale of the disaster zone of the event are recorded. At the same time, the fulfilment of at least one of the three specified criteria gives grounds to conclude that there is an emergency. The study showed that the number of emergencies is small, and one can observe their decrease in some types in 2020; however, each emergency event is human life, so it is necessary to strive to ensure that their number leads to 0 . The proposed measures will allow business structures to anticipate emergencies more effectively.

\section{$\underline{\text { References }}$}

1. Bashynska I.O., Alhammadi T.A.M.A., Alnuaimi H.R.S.A. Risk management in emergency situations. Economy. Finances. Law. 2020. №2/1, pp. 6-9.

2. Beigbeder, I. Natural and Man-Made Emergencies In book: New Challenges for UNICEF, 2001. DOI: 10.1057/9780230595576_6

3. Bashynska, I. Management of smartization of business processes of an industrial enterprise to ensure its economic security. Schweinfurt: Time Realities Scientific Group UG (haftungsbeschrankt), 2020. $420 \mathrm{p}$.

4. National Classifier "Classifier of Emergencies" DK 019: 2010. URL: https://zakon.rada.gov.ua/rada/show/va45760910\#Text (in Ukrainian).

5. Official site of the State Emergency Service of Ukraine https://www.dsns.gov.ua/ (in Ukrainian).

6. Smokvina G.A., Alhammadi Taleb Abdullah Mohammed Ali. Tools for assessing the personnel component of the financial and economic security of the enterprise. Entrepreneurship and innovation. 2021. pp. 50-56. (in Ukrainian).

7. Bryen N. Communication during times of natural or manmade emergencies. Journal of Pediatric Rehabilitation Medicine. 2009. №2(2). pp. 123-129. DOI: 10.3233/PRM-2009-0075

\section{Список використаних джерел}

1. Bashynska I.O., Alhammadi T.A.M.A., Alnuaimi H.R.S.A. Risk management in emergency situations. Економіка.Фінанси.Право. 2020. №2/1. С. 6-9.

2. Beigbeder, I. Natural and Man-Made Emergencies In book: New Challenges for UNICEF, 2001. DOI: 10.1057/9780230595576_6

3. Bashynska, I. Management of smartization of business processes of an industrial enterprise to ensure its economic security. Schweinfurt: Time Realities Scientific Group UG (haftungsbeschränkt), 2020. $420 \mathrm{p}$.

4. Національний класифікатор «Класифікатор надзвичайних ситуацій» ДК 019:2010. URL: https://zakon.rada.gov.ua/rada/ show/va457609-10\#Text

5. Офіційний сайт Державної служби України 3 надзвичайних ситуацій. https://www.dsns.gov.ua/

6. Смоквіна Г.А., Альхаммаді Талеб Абдулла Мохаммед Алі. Інструменти оцінки кадрового складника системи фінансовоекономічної безпеки підприємства. Підприємництво та інновачіï. 2021. С. 50-56.

7. Bryen N. Communication during times of natural or manmade emergencies. Journal of Pediatric Rehabilitation Medicine. 2009. №2(2). pp. 123-129. DOI: 10.3233/PRM-2009-0075

\section{Талеб Абдулла Мохаммед Алі АЛЬХАММАДІ}

аспірант, Державний університет "Одеська політехніка" ORCID: https://orcid.org/0000-0001-8364-989X

\section{Хамед Рашеа Саєд Абдулла АЛЬНУАІМІ}

аспірант, Державний університет "Одеська політехніка" ORCID: https://orcid.org/0000-0002-2479-1244

\section{НАДЗВИЧАЙНІ СИТУАЦІЇ В УКРАЇНІ: АНАЛІТИКО-СТАТИСТИЧНЕ ДОСЛІДЖЕННЯ}

Вступ. Знання причин та характеру надзвичайних ситуачій дозволяє в умовах раннього прийняття захисних заходів, із розумною поведінкою, значно зменшити всі види збитків. Попередня інформація для бізнес-структур дає можливість проводити профілактичну роботу, насторожувати сили та засоби, пояснювати людям правила поведінки. Усі бізнесструктури та населення повинні бути готові діяти в екстремальних ситуаціях, брати участь у ліквідації стихійних лих, аварій та катастроф, мати можливість опанувати методи надання першої допомоги потерпілим. Для вирішення цих питань більшість розвинених країн Свропи та Америки створили спеціальні медичні системи, основними завданнями яких $\epsilon$ реагування на надзвичайні ситуаиії та участь у ліквідації наслідків для здоров'я.

Мета статmі - дослідження рівня надзвичайних ситуацій в Украйні та розроблення профілактичних заходів для бізнесструктур.

Результати. У 2020 р. в Украӥні зареєстровано 116 надзвичайних ситуачій, серед яких техногенного характеру - 40,2 \%, природного характеру - 54,7 \%; соиіального характеру - 5,1\%. Також значно вплинуло захворювання людей на коронавірус COVID-19 - 18680 летальних випадків у 2020 р. Порівняно з 2019 р. загальна кількість адзвичайних ситуаиій у 2020 р. змениилася на 20,5\%. Аналіз показав, шо найбільи поширеними джерелами виникнення надзвичайних ситуаиій техногенного характеру $\epsilon$ пожежі і вибухи, які відбуваються на промислових об'єктах, тому автори запропонували попереджувальні заходи для бізнес-структур, в число яких включені заходи, спрямовані на усунення причин, які можуть призвести до виникнення пожежі (вибух), на обмеження (локалізацію) поширення, створення умов для евакуації людей і майна, своєчасне виявлення пожежі та оповіщення про це, гасіння пожежі, підтримання сил ліквідації пожеж у постійній готовності.

Висновок. Дослідження показало, щңо кількість надзвичайних ситуацій невелика і можна спостерігати їх зниження за деякими видами у 2020 р, проте кожне надзвичайна подія - ие людські життя, тому необхідно прагнути, щеб їх кількість вело до 0. Запропоновані заходи дозволять бізнес-структурам ефективніше передбачати надзвичайні ситуації.

Ключові слова: надзвичайні ситуачії, бізнес-структури, статистика 